\title{
Determination of protein degradation rates using a rumen in vitro system containing inhibitors of microbial nitrogen metabolism*
}

\author{
BY GLEN A. BRODERICK \\ US Department of Agriculture, Agricultural Research Service, \\ US Dairy Forage Research Center, 1925 Linden Drive West, University of Wisconsin, \\ Madison, Wisconsin, 53706, USA
}

(Received 13 January 1987- Accepted 8 June 1987)

\begin{abstract}
1. A previously reported rumen in vitro system (Broderick, 1978) was modified to include chloramphenicol (CAP) with hydrazine sulphate (HS) to give quantitative recovery of protein breakdown products. Degradation rates were determined by regression $v$. time of $\log$ proportion remaining undegraded (computed by subtracting from added nitrogen the amount of $\mathrm{N}$ recovered as ammonia and amino acids). Concentrations of reagents giving optimal $N$ recoveries and estimated degradation rates for casein and expeller soya-bean-meal (SBM) were: 1.0 $\mathrm{mm}$-HS, $30 \mu \mathrm{g} \mathrm{CAP} / \mathrm{ml}, 2.0 \mathrm{~mm}$-mercaptoethanol, $3.3 \mathrm{mg}$ maltose $/ \mathrm{ml}$, when protein was added at $0.125 \mathrm{mg} \mathrm{N} / \mathrm{ml}$.

2. Digestion of azo-casein and azo-albumin, solubilization of radioactivity from ${ }^{14} \mathrm{C}$-labelled casein, ovalbumin and bovine serum albumin (BSA), and hydrolysis of benzoyl-L-tyrosine p-nitroanilide and benzoyl-L-arginine $p$ nitroanilide were not significantly decreased by HS and CAP. This suggests that the inhibitors did not reduce microbial proteolysis.

3. Mean fractional degradation rates $(/ \mathrm{h})$ were : 0.395 casein, $0 \cdot 135 \mathrm{BSA}, 0 \cdot 159$ solvent-SBM, $0 \cdot 045$ expellerSBM, 0.061 meat meal, 0.070 lucerne (Medicago sativa) hay. Extents of protein escape, estimated assuming rumen passage of $0.06 / \mathrm{h}$, were $13,28,56$ and $40 \%$ for casein, solvent-SBM, expeller-SBM and lucerne hay respectively. This method appears more reliable for assessing rumen degradability than buffer $\mathrm{N}$ solubility and protein digestibility with ficin protease.

4. Azo-dye treatment slowed the rate of casein degradation, measured by ammonia plus amino acid release, but did not alter digestion of BSA.

5. The validity of the inhibitor in vitro method for estimating protein degradability, as well as potential problems in its application, are discussed. The complete procedure may be limited to laboratories with automated analytical equipment, but a simplified version of the method may be more generally applicable.
\end{abstract}

The value of a protein fed to ruminants is influenced substantially by the extent to which it is degraded in the rumen. Newly developed feeding systems (Agricultural Research Council, 1984; (US) National Research Council, 1985) have placed increased emphasis on rumen degradability of feed proteins. Also, it would be useful to quantify the effectiveness of processing (e.g. heat-treatment) on rumen degradation more easily. In vitro methods based on ammonia release (Broderick, 1982) and nitrogen solubility (Mangan, 1972; Mahadevan et al. 1980) are inadequate. Recently, commercial proteases have been proposed (Poos-Floyd et al. 1985; Krishnamoorthy et al. 1983) for this purpose, but their value has not been confirmed. In vivo methodology, in addition to being tedious, is limited by inaccurate differentiation between proteins of feed and microbial origin.

The purpose of the present report is to describe a modification of a previously developed rumen in vitro system for estimating protein degradation (Broderick, 1978). This method has been extended to estimate rumen degradation rates and extents of escape of common proteins. Also, degradabilities obtained with this procedure have been compared with $\mathrm{N}$ solubility, a protease technique and in vivo estimates of degradability for certain proteins. A preliminary report of some of this work has been published (Broderick, 1984).

\footnotetext{
* Mention of commercial products or sources in this paper does not constitute endorsement by the U.S. Department of Agriculture or the Agricultural Research Service.
} 


\section{MATERIALS AND METHODS}

\section{In vitro procedure}

Whole rumen contents were obtained from a rumen-cannulated lactating dairy cow fed on a diet of ( $\mathrm{g} / \mathrm{kg}$ dry matter (DM)): 300 maize silage, 300 lucerne (Medicago sativa) hay, 280 ground maize, 100 soya-bean meal (SBM) and 20 mineral and vitamin concentrate. The rumen in vitro inoculum was prepared by the method of Craig et al (1984). Strained rumen fluid (SRF) was obtained by tightly squeezing chilled rumen contents through two layers of cheesecloth. To extract some of the particle-associated organisms, the remaining solids residue was washed four times with a total volume of McDougall's buffer (McDougall, 1948) equal to the original volume of SRF. The SRF plus buffer extract were mixed, then filtered through eight layers of cheesecloth. Oxygen-free carbon dioxide (Hungate, 1969) was used to purge air from vessels and in preparation of McDougall's buffer.

Preliminary studies tested the effects of varying the concentrations of inhibitors, energy source (maltose) and protein in the incubation. The in vitro procedure finally adopted involved weighing $35-40 \mathrm{mg} \mathrm{N}$ from each finely ground protein sample into in vitro flasks (no. 1960-00250; Bellco, Vineland, NJ) equipped with magnetic stirrers, side-arms and bunsen valves (it was later found that bunsen valves were unnecessary). Samples were wetted for about $1 \mathrm{~h}$ by addition of $100 \mathrm{ml} \mathrm{McDougall's} \mathrm{buffer} \mathrm{at} 39^{\circ}$. Effects of varying the levels of the inhibitors hydrazine sulphate (HS) and chloramphenicol (CAP) on recoveries of $\mathrm{NH}_{3}$ and total $\mathrm{N}$ (added as ammonium sulphate and amino acids from acidhydrolyzed casein), and apparent degradation rate were also studied.

The SRF plus buffer extract was slowly warmed to $39^{\circ}$ in a water-bath, then appropriate reagent volumes (Table 1) were added to the inoculum about $5 \mathrm{~min}$ before starting the incubation. Maltose solution was made fresh daily; HS and CAP were prepared weekly and stored at $4^{\circ}$. Microbial DM was estimated in quadruplicate by centrifuging $(15 \mathrm{~min}$, $\left.31000 \mathrm{~g}, 4^{\circ}\right) 10 \mathrm{ml}$ portions of inoculum, discarding supernatant fractions, and drying pellets at $60^{\circ}$ for $48 \mathrm{~h}$. Incubations were begun by dispensing $200 \mathrm{ml}$ of the inoculum to each flask using a graduated cylinder; the inoculum was stirred continuously while dispensing to prevent sedimentation. Both inoculum vessel and in vitro flasks were flushed with $\mathrm{CO}_{2}$ during this process. During incubations, in vitro flasks were stirred at 75-100 rev./min by means of a heavy duty, four-position magnetic stirrer which supported four four-position 'piggy-back' stirrers (nos. 7760-06065 and 7762-10004; Bellco); temperature was maintained at $39^{\circ}$ in a warm room. Incubations were run for $4 \mathrm{~h}$, with sampling immediately after adding the inoculum (zero time), and (except where recoveries of $\mathrm{NH}_{3}$ and $\mathrm{N}$ were determined) every $30 \mathrm{~min}$ thereafter. Duplicate blank flasks (i.e. with all components except protein) were included in each incubation; incubations were replicated three or four times.

Effects of arresting microbial activity with various 'kill' reagents were tested, but the method finally adopted to stop protein degradation was as follows. The stirring rate of the flask was increased to about $200 \mathrm{rev} . / \mathrm{min}$, one side-arm uncapped, a $\mathrm{CO}_{2}$ probe inserted, a $4 \mathrm{ml}$ portion of medium withdrawn using a repeating pipetter and transferred to a glass tube kept in ice; the flask was recapped and returned to the original stirring rate. Duplicate $1 \mathrm{ml}$ portions of chilled sample were transferred to $12 \times 75 \mathrm{~mm}$ disposable centrifuge tubes containing $0.25 \mathrm{ml}$ trichloroacetic acid $(250 \mathrm{~g} / 1$; TCA), kept in ice for $30-45 \mathrm{~min}$, then centrifuged $\left(15 \mathrm{~min}, 15300 \mathrm{~g}, 4^{\circ}\right)$. Supernatant fractions were stored at $4^{\circ}$ until analysed. An equally effective procedure was to add the $4 \mathrm{ml}$ sample directly to tubes kept in ice and containing $1 \mathrm{ml}$ methylene chloride solution with cetyltrimethylammonium bromide $(40 \mathrm{~g} / 1$, CTAB) and TCA $(20 \mathrm{~g} / 1)$. After stirring on a vortex mixer and holding on ice for $30-45$ 
Table 1. Composition of in vitro inoculum and reagent concentrations in the final medium

\begin{tabular}{lcc}
\hline \hline Component & $\begin{array}{c}\text { Inoculum } \\
\text { concentration } \\
\text { (amount/l) }\end{array}$ & $\begin{array}{c}\text { Final medium } \\
\text { concentration }\end{array}$ \\
\hline Strained rumen fluid & $450 \mathrm{ml}$ & $300 \mathrm{ml} / 1$ \\
Buffer extract of rumen solids & $450 \mathrm{ml}$ & $300 \mathrm{ml} / 1$ \\
McDougall's buffer & 0 & $400 \mathrm{ml} / 1$ \\
2-Mercaptoethanol* & $234 \mathrm{mg}$ & $2 \cdot 0 \mathrm{mM}$ \\
Maltose solution $(100 \mathrm{mg} / \mathrm{ml})^{*}$ & $50 \mathrm{ml}$ & $3.3 \mathrm{mg} / \mathrm{ml}$ \\
Hydrazine solution $(60 \mathrm{mM})^{*}$ & $25 \mathrm{ml}$ & $30 \cdot 0 \mu \mathrm{mm} / \mathrm{ml}$ \\
Chloramphenicol solution $(1.80 \mathrm{mg} / \mathrm{ml})^{*}$ & $25 \mathrm{ml}$ & $30 \cdot 0$ \\
\hline \hline
\end{tabular}

* Maltose, hydrazine sulphate and chloramphenicol solutions prepared in McDougall's buffer (McDougall, 1948). Reagents were added to the inoculum in the order: 2-mercaptoethanol, maltose, hydrazine sulphate then chloramphenicol.

min, a portion of the aqueous (top) phase was decanted, centrifuged and stored as described previously.

\section{Chemical analysis}

In vitro samples were analysed for $\mathrm{NH}_{3}$ and total amino acids (TAA) by the semiautomated method of Broderick \& Kang (1980), except that dialysis was used in both manifolds, sample rate was $90 / \mathrm{h}$ and automated data collection and analysis were used. Protein samples were finely ground using a cyclone mill (Udy Corp., Fort Collins, CO) before in vitro incubations and analysis for total $\mathrm{N}$ and DM (Association of Official Analytical Chemists, 1980), N soluble in McDougall's buffer (Craig \& Broderick, 1981), and $\mathrm{N}$ solubilized by incubation for $4 \mathrm{~h}$ in 0.23 unit ficin protease/ml (Poos-Floyd et al. 1985). Indigestible $N$ (IDN) was estimated as the $N$ insoluble after treatment for $48 \mathrm{~h}$ with 6.6 units Streptomyces griseus protease/ml (Krishnamoorthy et al. 1983). Acid-hydrolysates $\left(6 \mathrm{M}\right.$-hydrochloric acid, $\left.20 \mathrm{~h}, 105^{\circ}\right)$ of proteins were analysed for TAA with the same analytical system used for in vitro samples.

Degradation of diazotized proteins was determined from disappearance of azo dye from the TCA precipitate, rather than from appearance of dye in the in vitro medium (Mahadevan et al. 1979). Hydrolysis of the artificial chymotrypsin (EC 3.4.21.1) and trypsin (EC 3.4.21.4) substrates, benzoyl-L-tyrosine $p$-nitroanilide (BTPNA) and benzoylL-arginine $p$-nitroanilide (BAPNA), was determined from appearance of $p$-nitroaniline (Appel, 1974). Degradation of casein, ovalbumin and bovine serum albumin (BSA), previously labelled with ${ }^{14} \mathrm{C}$ by reductive methylation, was followed by accumulation of ${ }^{14} \mathrm{C}$ in the TCA-supernatant fraction (Wallace, 1983).

\section{Mathematical computations}

Recoveries after $4 \mathrm{~h}$ of $\mathrm{NH}_{3}$ and TAA-N, added to incubations as ammonium sulphate and acid-hydrolyzed casein, were computed using the equations

$$
\text { Ammonia recovery }(\%)=\frac{\mathrm{NH}_{3}-\mathrm{H}}{\mathrm{NH}_{3}-\mathrm{N} \text { added }} \times 100 \text {, }
$$

and

$$
\mathrm{N} \text { recovery }(\%)=\frac{\mathrm{NH}_{3}-\mathrm{N}+\mathrm{TAA}-\mathrm{N}}{\operatorname{added} \mathrm{N}} \times 100
$$


where TAA-N recovered was computed from the TAA content of acid-hydrolysis of casein $(46.5 \mu \mathrm{mol} / \mathrm{mg} \mathrm{N})$. The proportion degraded (PD) for each protein sample at each timepoint $(t)$ was computed using the equation

$$
\mathrm{PD}=\frac{\operatorname{mg~NH} \mathrm{N}_{3} \mathrm{~N}(\text { at } t)+(\mu \mathrm{mol} \mathrm{TAA}(\text { at } t)) /(\mu \mathrm{mol} \mathrm{TAA} / \mathrm{mg} \mathrm{N})}{\mathrm{mg} \text { added } \mathrm{N}}
$$

$\mathrm{N}$ and TAA contents of specific proteins were determined as described earlier. Net $\mathrm{NH}_{3}$ and TAA released (i.e. minus $\mathrm{NH}_{3}$ and TAA levels in blank incubations) were corrected for analytical recoveries of added $\mathrm{NH}_{3}$ and leucine (the standard amino acid), and for sample volume and dilution.

Fractional degradation rates were computed using a single-exponential, first-order model without time lag (McDonald, 1981; Agricultural Research Council, 1984; (US) National Research Council, 1985). The proportion undegraded (PUD) was assumed to be one minus PD. When IDN for a protein was less than $1 \%$ of total $\mathrm{N}$, fractional degradation rate $\left(K_{d}\right)$ was determined directly as the slope obtained by linear regression of natural logarithms of PUD $v$. time. When IDN was greater than $1 \%, K_{d}$ was the slope from regression of the natural logarithm of (PUD - IDN) v. time. Casein had PD greater than $80 \%$ by $3 \mathrm{~h}$, hence regression was stopped at this time. All other regressions were over $4 \mathrm{~h}$. Degradation fractions in this system correspond to those of the (US) National Research Council (1985) as follows: one minus the intercept antilog was equivalent to fraction $A$, protein already degraded at zero-time (i.e. non-protein-N (NPN) already in the form of $\mathrm{NH}_{3}$ and amino acids); the intercept antilog, PUD (when IDN $<1 \%$ ) or PUD - IDN (when IDN $>1 \%$ ), corresponded to fraction $B$ (degradable true protein); IDN was equivalent to fraction $C$ (protein which was completely indigestible). Fractional degradation rate was defined by Ørskov \& McDonald (1979) as ' $c$ ' rather than $K_{d}$. Estimated protein escape from the rumen was computed (Ørskov \& McDonald, 1979; McDonald, 1981; (US) National Research Council, 1985):

$$
\text { estimated protein escape }(\%)=\left(B\left[K_{p} /\left(K_{d}+K_{p}\right)\right]+C\right) \times 100 \text {. }
$$

Rumen passage rate $\left(K_{p}\right)$ was assumed to be $0 \cdot 06 / \mathrm{h}$, similar to rates of DM passage reported for lactating dairy cows (Hartnell \& Satter, 1979; Eliman \& Ørskov, 1984).

\section{Chemicals}

The following chemicals were obtained from Sigma (St Louis, MO): casein, BSA, azocasein, azo-albumin, BTPNA, BAPNA, acid-hydrolyzed casein, ammonium sulphate, HS, CAP, 2-mercaptoethanol, maltose, ficin protease (no. F8629) and Streptomyces griseus protease Type XIV (no. P5147). The casein, ovalbumin and BSA labelled with ${ }^{14} \mathrm{C}$ were obtained from Dr R. J. Wallace of the Rowett Research Institute. All other reagents were of analytical grade or similar purity.

\section{Statistical methods}

Statistical procedures were those of Steel \& Torrie (1960). One-way analysis of variance was used; when significant treatment effects were observed, mean separations were by least significant difference. Linear regressions with computation of correlation coefficients $(r)$, slopes with their standard errors, and intercepts were conducted. Improvement of fit with non-linear regression $v$. linear regression was tested in one experiment. 
Table 2. Effect of hydrazine (HS) and chloramphenicol (CAP) on recovery of nitrogen added to rumen in vitro incubations as ammonium sulphate, a low level of casein hydrolysate (low $N$ ) or a high level of casein hydrolysate (high $N$ ), and on fractional degradation rates of casein and expeller soya-bean-meal (SBM)

(Recoveries and degradation rates are means from three $4 \mathrm{~h}$ incubations. Medium contained $6.7 \mathrm{mg}$ maltose $/ \mathrm{ml}$ and averaged $13.11 \mathrm{mg}$ microbial dry matter $/ \mathrm{ml}$. Amounts added: ammonia $4.18 \mathrm{~mm}$, low$\mathrm{N} 1.16 \mathrm{mM}^{-\mathrm{NH}_{3}}$ and $0.99 \mathrm{~mm}$-total amino acids (TAA), high- $\mathrm{N} 2.35 \mathrm{~mm}-\mathrm{NH}_{3}$ and $3.84 \mathrm{~mm}-\mathrm{TAA}$, casein and expeller-SBM $0.25 \mathrm{mg} \mathrm{N} / \mathrm{ml}$ )

\begin{tabular}{|c|c|c|c|c|c|c|}
\hline \multicolumn{2}{|c|}{ Inhibitor } & \multirow{2}{*}{\multicolumn{3}{|c|}{ Recovery (\%) }} & \multirow{2}{*}{\multicolumn{2}{|c|}{ Degradation rate $(/ h)$}} \\
\hline \multirow{2}{*}{$\begin{array}{c}\mathrm{HS} \\
(\mathrm{mM})\end{array}$} & \multirow{2}{*}{$\begin{array}{c}\text { CAP } \\
(\mu \mathrm{g} / \mathrm{ml})\end{array}$} & & & & & \\
\hline & & $\mathrm{NH}_{3}$ & Low $\mathrm{N}$ & High $N$ & Casein & Expeller-SBM $\dagger$ \\
\hline 0 & 0 & $21 \cdot 6^{c}$ & $-14 \cdot 3^{c}$ & $44 \cdot 5^{c}$ & $0 \cdot 163^{d}$ & $0.005^{\mathrm{d}}$ \\
\hline 0 & 10 & $29 \cdot 6^{\circ}$ & $-8 \cdot 8^{\mathrm{c}}$ & $55 \cdot 6^{\mathrm{b}}$ & $0 \cdot 197^{c, d}$ & $0.012^{c, d}$ \\
\hline 0 & 30 & $46 \cdot 7^{b}$ & $-3 \cdot 9^{c}$ & $62 \cdot 2^{\mathrm{b}, \mathrm{c}}$ & $0.254^{\mathrm{c}}$ & $0.019^{\varepsilon}$ \\
\hline 0 & 100 & $86 \cdot 8^{\mathrm{a}}$ & $65 \cdot 1^{\mathrm{D}}$ & $88 \cdot 1^{\mathrm{a}}$ & $0 \cdot 419^{\mathrm{a}}$ & $0.043^{b}$ \\
\hline $1 \cdot 0$ & 0 & $91 \cdot 0^{\mathrm{a}}$ & $83 \cdot 9^{a, b}$ & $88 \cdot 8^{\mathrm{a}}$ & $0.329^{\mathrm{b}}$ & $0.044^{\mathrm{b}}$ \\
\hline $1 \cdot 0$ & 10 & $94 \cdot 1^{\mathrm{a}}$ & $83 \cdot 3^{a, b}$ & $88 \cdot 7^{\mathrm{a}}$ & $0 \cdot 331^{\mathrm{b}}$ & $0.048^{\mathrm{b}}$ \\
\hline $1 \cdot 0$ & 30 & $96 \cdot 8^{\mathrm{a}}$ & $93 \cdot 6^{a}$ & $94 \cdot 5^{\mathrm{a}}$ & $0 \cdot 395^{\mathrm{a}, \mathrm{b}}$ & $0.069^{\mathrm{a}}$ \\
\hline $1 \cdot 0$ & 100 & $98 \cdot 1^{\mathrm{a}}$ & $92 \cdot 8^{\mathrm{a}}$ & $93 \cdot 3^{a}$ & $0-369^{\mathrm{a}, \mathrm{b}}$ & $0.072^{\mathrm{a}}$ \\
\hline $\mathbf{S E}$ & & $4 \cdot 8$ & 6.7 & $4 \cdot 4$ & $0 \cdot 024$ & 0.004 \\
\hline
\end{tabular}

a, b,c, d Significant treatment effect $(P<0.001)$ in each case. Mean values in vertical columns not sharing a common superscript letter were significantly different $(P<0.05)$.

$\dagger$ Received October 1983.

\section{RESULTS}

\section{Inhibitors and $N$ recovery}

To apply this method, it is necessary to obtain essentially complete recovery of protein degradation products. Previously, $1 \mathrm{~mm}-\mathrm{HS}$ was found to give nearly $100 \%$ recovery of $\mathrm{NH}_{3}$ and high levels of $\mathrm{N}$ added as acid-hydrolysed casein (Broderick, 1978). HS and CAP were tested together (Table 2) in degradation and recovery studies conducted with $\mathrm{NH}_{3}$ and both low and high concentrations of added $\mathrm{N}$ (corresponding to $\mathrm{NH}_{3}$ and TAA released after $4 \mathrm{~h}$ from degradation of expeller-SBM and casein respectively). $\mathrm{NH}_{3}$ recovery was higher with HS alone than CAP alone; there was no significant improvement when CAP was added to HS (Table 2). Recovery of low $\mathrm{N}$ was maximal only when at least $30 \mu \mathrm{g} \mathrm{CAP} / \mathrm{ml}$ was included with HS. Similar results were found with the higher level of added $\mathrm{N}$. Comparable degradation rates for casein were obtained at $100 \mu \mathrm{g} \mathrm{CAP} / \mathrm{ml}$ and $1 \mathrm{~mm}-\mathrm{HS}$ plus $30 \mu \mathrm{g} \mathrm{CAP} / \mathrm{ml}$. However, degradation of expeller-SBM was similar in pattern to recovery of low $\mathrm{N}$-maximal when at least $30 \mu \mathrm{g} \mathrm{CAP} / \mathrm{ml}$ was added to $1 \mathrm{~mm}$ HS. Recovery of $\mathrm{N}$ and apparent degradation rates were not improved by adding $100 \mu \mathrm{g}$ $\mathrm{CAP} / \mathrm{ml}$ to $\mathrm{HS}$. Therefore degradation rates were determined using $1 \mathrm{mM}-\mathrm{HS}$ plus $30 \mu \mathrm{g}$ $\mathrm{CAP} / \mathrm{ml}$ during in vitro incubations.

\section{Maltose concentration}

The influence on apparent degradation rate of adding energy as maltose was reinvestigated. When the incubation contained $1 \mathrm{mM}-\mathrm{HS}$ and $30 \mu \mathrm{g} \mathrm{CAP} / \mathrm{ml}$, maltose increased apparent degradation of all four proteins studied, although there was statistical significance only for solvent-SBM (Table 3). Degradation rates were maximal for casein, BSA and solvent-SBM at $3.3 \mathrm{mg}$ maltose $/ \mathrm{ml}$. 
Table 3. Effect of maltose concentration in rumen in vitro incubations on fractional degradation rates of casein, bovine serum albumin (BSA), solvent and expeller soya-beanmeal (SBM)

(Degradation rates $(/ \mathrm{h})$ are means from two $3 \mathrm{~h}$ incubations. Medium contained $1.0 \mathrm{~mm}$-hydrazine plus $30 \mu \mathrm{g}$ chloramphenicol $/ \mathrm{ml}$, and $9.77 \mathrm{mg}$ microbial dry matter $/ \mathrm{ml}$; protein added at $0.25 \mathrm{mg}$ nitrogen $/ \mathrm{ml}$ ).

\begin{tabular}{|c|c|c|c|c|}
\hline \multirow{2}{*}{$\begin{array}{l}\text { Maltose } \\
\text { concentration } \\
(\mathrm{mg} / \mathrm{ml})\end{array}$} & \multicolumn{4}{|c|}{ Protein } \\
\hline & Casein & BSA & Solvent-SBM $\dagger$ & Expeller-SBM $\dagger$ \\
\hline 0 & $0 \cdot 274$ & 0.065 & $0 \cdot 113^{b}$ & $0 \cdot 064$ \\
\hline 0.67 & $0 \cdot 298$ & 0.067 & $0 \cdot 135^{\mathrm{a}}$ & 0.064 \\
\hline $1 \cdot 33$ & 0.304 & 0.069 & $0 \cdot 143^{a}$ & 0.077 \\
\hline $3 \cdot 3$ & 0.326 & 0.071 & $0 \cdot 142^{\mathrm{a}}$ & $0 \cdot 084$ \\
\hline $6 \cdot 7$ & 0.259 & 0.068 & $0 \cdot 135^{\mathrm{a}}$ & 0.090 \\
\hline $\mathrm{SE}$ & 0.033 & $0 \cdot 008$ & 0.006 & 0.020 \\
\hline Statistical significance & NS & NS & $P<0.05$ & NS \\
\hline
\end{tabular}

NS, not significant $(P>0 \cdot 10)$.

$\mathrm{a}, \mathrm{b}$ Mean values in solvent-SBM column not sharing a common superscript letter were significantly different $(P<0.05)$.

+ Received October 1983 .

Table 4. Effect of concentration of protein added to the rumen in vitro incubation on degradation variables obtained for casein, bovine serum albumin (BSA), and solvent and expeller soya-bean-meal (SBM)

(Values are means with their standard errors from three $3 \mathrm{~h}$ incubations, with samples taken at $0.5 \mathrm{~h}$

intervals. Medium contained 1.0 mM-hydrazine plus $30 \mu \mathrm{g}$ chloramphenicol $/ \mathrm{ml}, 3.3 \mathrm{mg} \mathrm{maltose} / \mathrm{ml}$, and $6.52 \mathrm{mg}$ microbial dry matter $/ \mathrm{ml}$ )

\begin{tabular}{|c|c|c|c|c|c|c|}
\hline \multirow[b]{2}{*}{ Protein } & \multirow{2}{*}{$\begin{array}{l}\text { Nitrogen } \\
\text { concentration } \\
(\mathrm{mg} / \mathrm{ml})\end{array}$} & \multirow{2}{*}{$\begin{array}{l}\text { Statistical } \\
\text { significance }\end{array}$} & \multirow[b]{2}{*}{$r$} & \multicolumn{2}{|c|}{$\begin{array}{l}\text { Degradation } \\
\text { rate }(/ \mathrm{h})\end{array}$} & \multirow{2}{*}{$\begin{array}{c}\text { Intercept } \\
\text { antilog (\%) }\end{array}$} \\
\hline & & & & Mean & $\mathrm{SE}$ & \\
\hline Casein & $\left.\begin{array}{l}0.125 \\
0.25\end{array}\right\}$ & $P<0.005$ & $\left\{\begin{array}{l}0.931 \\
0.983\end{array}\right.$ & $\begin{array}{l}0.369 \\
0.190\end{array}$ & $\begin{array}{l}0.036 \\
0.009\end{array}$ & $\begin{array}{l}103 \cdot 3 \\
101 \cdot 2\end{array}$ \\
\hline BSA & $\left.\begin{array}{l}0.125 \\
0.25\end{array}\right\}$ & $P<0.01$ & $\left\{\begin{array}{l}0.858 \\
0.917\end{array}\right.$ & $\begin{array}{l}0.113 \\
0.058\end{array}$ & $\begin{array}{l}0.017 \\
0.006\end{array}$ & $\begin{array}{l}106 \cdot 2 \\
102 \cdot 0\end{array}$ \\
\hline Solvent-SBM ${ }^{\dagger}$ & $\left.\begin{array}{l}0 \cdot 125 \\
0.25\end{array}\right\}$ & $P<0 \cdot 10$ & $\left\{\begin{array}{l}0.909 \\
0.953\end{array}\right.$ & $\begin{array}{l}0.176 \\
0.123\end{array}$ & $\begin{array}{l}0.020 \\
0.010\end{array}$ & $\begin{array}{l}103 \cdot 4 \\
101 \cdot 3\end{array}$ \\
\hline Expeller-SBM $\dagger$ & $\left.\begin{array}{l}0.125 \\
0.25\end{array}\right\}$ & NS & $\left\{\begin{array}{l}0.953 \\
0.932\end{array}\right.$ & $\begin{array}{l}0 \cdot 110 \\
0 \cdot 102\end{array}$ & $\begin{array}{l}0.009 \\
0.010\end{array}$ & $\begin{array}{r}99 \cdot 2 \\
100 \cdot 7\end{array}$ \\
\hline
\end{tabular}

NS, not significant $(P>0 \cdot 10) ; r$, correlation coefficient.

$\dagger$ Received October 1983.

\section{Protein concentration}

Previously, when only HS was used in the inhibitor system, proteins were added at $0.1-0.15 \mathrm{mg} \mathrm{N} / \mathrm{ml}$ medium (Broderick, 1978; Broderick \& Craig, 1980). Later, protein concentration was increased twofold because degradative activity was approximately doubled by extracting particle-associated organisms (Craig et al. 1984). Doubling protein 
Table 5. Rumen degradation rates obtained for four proteins using previous in vitro system $(A ; B r o d e r i c k, 1984)$ and updated in vitro system $(B)$

(Degradation rates $(/ \mathrm{h})$ are mean values with their standard errors from three $3 \mathrm{~h}$ incubations. In vitro medium A contained $1.0 \mathrm{~mm}$-hydrazine and $6.7 \mathrm{mg}$ maltose $/ \mathrm{ml}$, with protein added at $0.25 \mathrm{mg}$ nitrogen/ $\mathrm{ml}$. In vitro medium B contained $1.0 \mathrm{~mm}$-hydrazine plus $30 \mu \mathrm{g}$ chloramphenicol $/ \mathrm{ml}$ and $3.3 \mathrm{mg}$ maltose/ $\mathrm{ml}$, with protein added at $0.125 \mathrm{mg} \mathrm{N} / \mathrm{ml}$ )

\begin{tabular}{|c|c|c|c|c|c|c|}
\hline \multirow[b]{3}{*}{ Protein } & \multicolumn{4}{|c|}{ In vitro system } & \multirow[b]{3}{*}{$\mathrm{B} / \mathrm{A}$} & \multirow{3}{*}{$\begin{array}{c}\text { Statistical } \\
\text { significance }\end{array}$} \\
\hline & \multicolumn{2}{|c|}{ A } & \multicolumn{2}{|c|}{ B } & & \\
\hline & Mean & SE & Mean & $\mathrm{SE}$ & & \\
\hline Casein & 0.274 & 0.0145 & $0 \cdot 373$ & $0-0267$ & $1 \cdot 36$ & $P<0.025$ \\
\hline Bovine serum albumin & 0.073 & 0.0054 & 0.135 & 0.0183 & 1.85 & $P<0.025$ \\
\hline Solvent-SBM† & 0.094 & 0.0039 & $0 \cdot 154$ & 0.0149 & $1 \cdot 64$ & $P<0.025$ \\
\hline Expeller-SBM $\dagger$ & 0.033 & 0.0036 & 0.046 & 0.0043 & $\begin{array}{c}1.39 \\
1.56(\operatorname{sE~} 0 \cdot 12)\end{array}$ & $P<0.10$ \\
\hline
\end{tabular}

SBM, Soya-bean meal. † Received January 1984.

concentration lowered standard errors of estimated degradation rates, but also reduced apparent degradation rates for three of four proteins studied (Table 4). Although precision was improved at $0.25 \mathrm{mg} \mathrm{N} / \mathrm{ml}$, the lower protein concentration of $0.125 \mathrm{mg} \mathrm{N} / \mathrm{ml}$ corresponds more closely to first-order conditions (Krishnamoorthy et al. 1983).

\section{Verification of in vitro system}

The in vitro system as previously used (system A) was compared with the updated system (system B) for four proteins (Table 5). The increase in apparent rate of protein degradation ranged from 36 (casein) to $85 \%$ (BSA), and was significant for all four proteins. Casein degradation rate was previously estimated to be $0.46 / \mathrm{h}$ in vivo (Broderick, 1978). The relative rumen protein escape of expeller-SBM (received January 1984) was found to be $64 \%$ greater than solvent-SBM (received January 1984) during in vivo studies (Broderick, 1986). Rumen escape of expeller-SBM, estimated from in vitro values in the present study, was $102 \%$ greater than solvent-SBM.

The effect of inhibitor on alternative indicators of protein degradative activity was studied using azo-labelled proteins (Mahadevan et al. 1979), BTPNA and BAPNA (Appel, 1974), and ${ }^{14} \mathrm{C}$-labelled proteins (Wallace, 1983). Addition of $1.0 \mathrm{~mm}-\mathrm{HS}$ and $30 \mu \mathrm{g}$ $\mathrm{CAP} / \mathrm{ml}$, either singly or in combination, did not significantly reduce degradation of azodye-labelled proteins or $p$-nitroanilide hydrolysis (Table 6). Although degradation of ${ }^{14} \mathrm{C}$ labelled casein was not influenced by inhibitor, there was a trend for degradation of ${ }^{14} \mathrm{C}$-labelled ovalbumin and BSA to be reduced at $\mathrm{HS}$ concentrations greater than $1.0 \mathrm{mM}$. However, degradation rates obtained for ovalbumin and BSA at $1.0 \mathrm{~mm}-\mathrm{HS}$ plus $30 \mu \mathrm{g}$ $\mathrm{CAP} / \mathrm{ml}$ were not different from control (Table 6).

\section{Application of method}

Table 7 summarizes chemical, solubility and in vitro degradation values from eleven protein sources. Degradations of the soluble proteins casein and BSA were similar to those observed earlier (Tables 4 and 5). Degradability for BSA was only one-third that of casein, reflecting the lack of correlation between degradation and solubility for certain proteins (Mangan, 1972). Little variation was observed in chemical and in vitro analyses conducted on solvent- and expeller-SBM. Ficin-soluble $\mathrm{N}$ was similar for both types of SBM. 

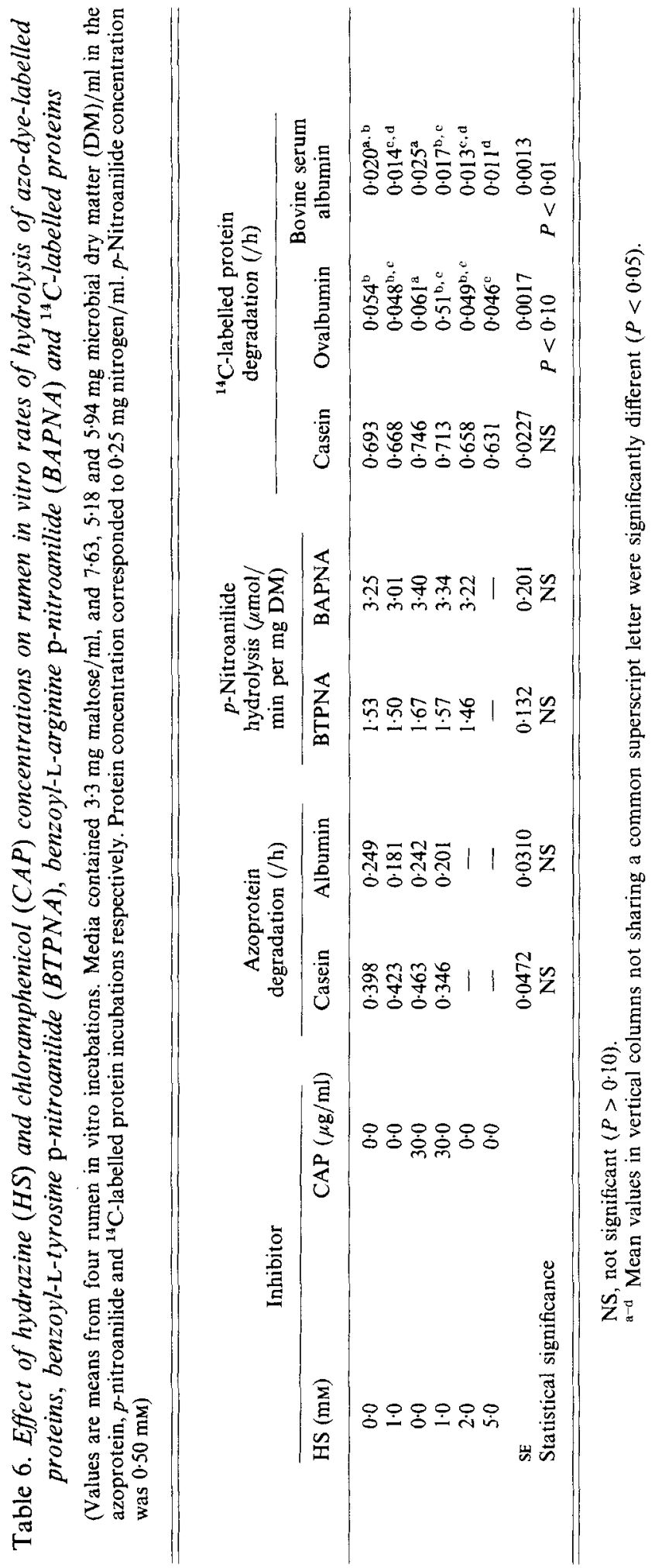
Rumen in vitro protein degradation rates

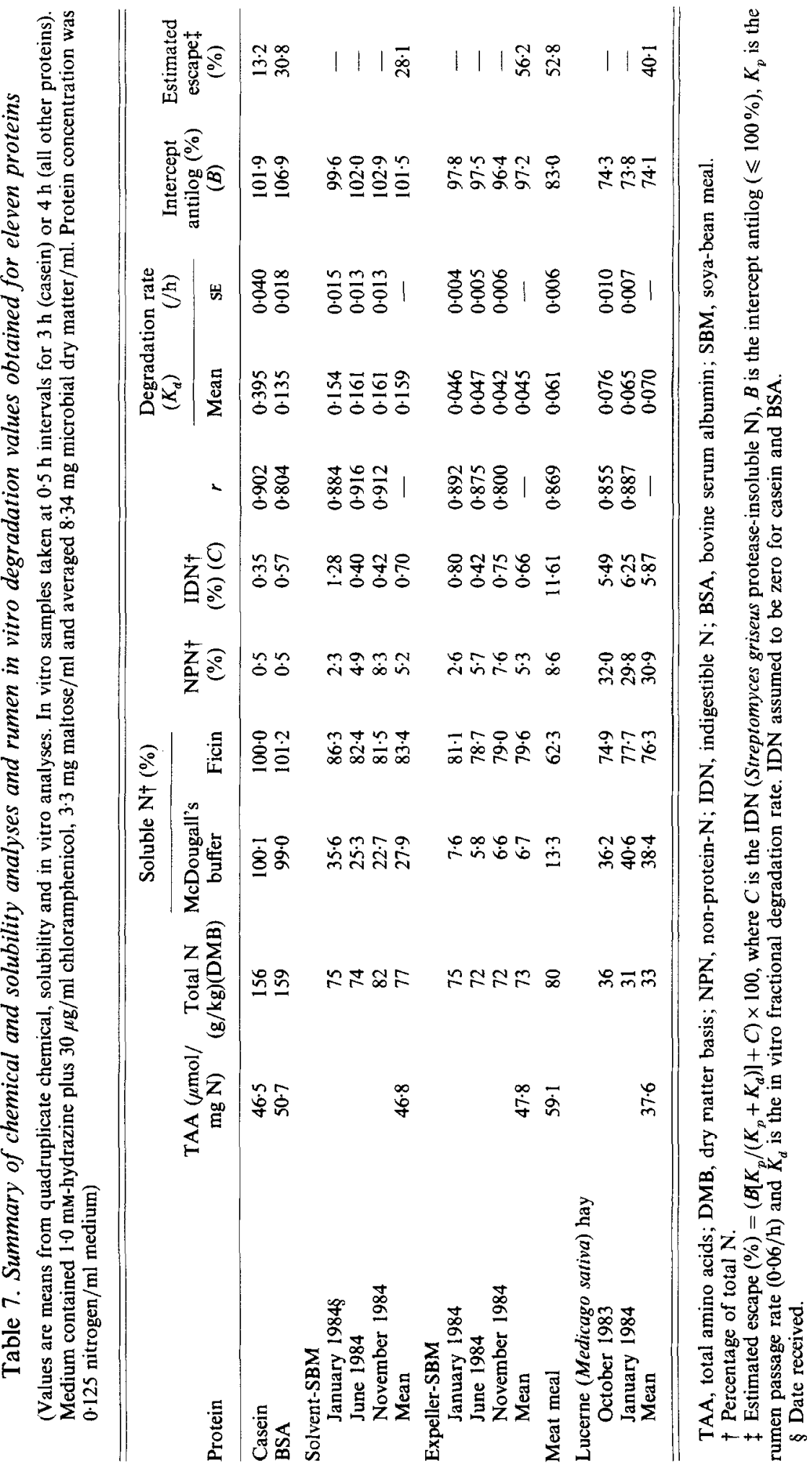




\section{DISCUSSION \\ Validity of method}

It is well known that estimation of protein degradation from appearance of breakdown products such as amino acids and $\mathrm{NH}_{3}$ is confounded by microbial uptake for growth. In the rumen in vitro system used here, HS and CAP are added to inhibit microbial metabolism of amino acids and $\mathrm{NH}_{3}$. Chloramphenicol interrupts bacterial protein synthesis by blocking formation of amino acyl-tRNA (Mahler \& Cordes, 1966). Addition of CAP at $30 \mu \mathrm{g} / \mathrm{ml}$ (Gale \& Folkes, 1953) improved $\mathrm{N}$ recovery in incubations containing low amounts of added $\mathrm{NH}_{3}$ and amino acids (Table 2). Although $\mathrm{HS}$ is a satisfactory inhibitor of amino acid deamination (Broderick \& Balthrop, 1979) and $\mathrm{NH}_{3}$ incorporation (Table 2), direct utilization of amino acids for microbial protein synthesis appeared to continue in the presence of HS alone. The combination of HS and CAP was effective for obtaining high recoveries of $\mathrm{N}$ from amino acids and ammonia (Table 2) and yielded the highest degradation rates, particularly for slowly degraded proteins (Tables 2 and 5), while not significantly reducing proteolysis (Table 6).

Other inhibitors or combinations of inhibitors which give rise to nearly complete recoveries of protein breakdown products would suffice for this application, so long as they did not inhibit microbial proteolysis. Use of CAP alone at $100 \mu \mathrm{g} / \mathrm{ml}$ yielded apparently high degradation rates for casein (Table 2), but has not been studied further. Raab et al. (1983) estimated rumen protein degradation from $\mathrm{NH}_{3}$ production by using gas formation to correct in vitro production rates for $\mathrm{NH}_{3}$ utilization for microbial growth.

It is interesting that addition of the energy substrate maltose tended to increase the protein degradation rate (Table 3). Energy supplementation would not stimulate microbial utilization of $\mathrm{NH}_{3}$ and amino acids because HS and CAP inhibit growth. Maltose addition may increase degradation rates by improving anaerobiosis and thereby increasing proteolytic activity (Cotta \& Hespell, 1986).

Mahadevan et al. (1979) labelled feed proteins with azo dyes, a procedure used previously to prepare substrates for proteolytic enzymes. Degradation of commercially prepared azocasein, estimated from $\mathrm{NH}_{3}$ and amino acid accumulation in vitro, was found to be significantly lower than control casein (Table 8). However, azo-albumin was degraded at the same rate as control BSA. This suggests that diazotization of proteins may alter their degradation. Degradation rates observed for azo-casein and azo-albumin determined from $\mathrm{NH}_{3}$ and amino acid release (Table 8 ) were 39 and $56 \%$ of the rates determined for the same proteins from azo-dye disappearance at $1.0 \mathrm{~mm}-\mathrm{HS}$ plus $30 \mu \mathrm{g} \mathrm{CAP} / \mathrm{ml}$ (Table 6). Wallace (1983) proposed labelling proteins with ${ }^{14} \mathrm{C}$ by reductive methylation and estimating degradation from solubilization of radioactivity. Reductive methylation reacts only about $1 / 200$ of the lysine residues in casein, does not alter casein degradation rate and appears to be satisfactory for soluble proteins. While useful for preparing soluble substrates for proteolytic enzymes, the method may not be generally applicable to common feed proteins which are mixtures of soluble and insoluble proteins (R. J. Wallace, personal communication).

Digestions with ficin protease (Poos-Floyd et al. 1985) and Streptomyces griseus protease (Krishnamoorthy et al. 1983) have been used to estimate rumen protein degradability in vitro. Solubilization of $\mathrm{N}$ with ficin did not appear to be sensitive to substantial differences in degradability between solvent- and expeller-SBM (Table 7). The method of Krishnamoorthy et al. (1983) for estimating degradability was not tested, but their procedure for quantifying indigestible protein was employed. The mean of $5.9 \%$ IDN for lucerne hay (Table 7) compares favourably with the acid-detergent-insoluble $\mathrm{N}$ value of $6.9 \%$ determined on the same samples. 
Table 8. Effect of azo-dye treatment on degradation rate estimated from release of ammonia and total amino acids in rumen in vitro incubations

(Degradation rates are overall means from incubations in which the effect of hydrazine or chloramphenicol, or both, was not significant $(P>0-10)$. Values are from four $3 \mathrm{~h}$ incubations containing $3.3 \mathrm{mg}$ maltose $/ \mathrm{ml}$, averaging $7.63 \mathrm{mg}$ microbial dry matter $/ \mathrm{ml}$. Protein concentrations corresponded to $0.25 \mathrm{mg}$ nitrogen $/ \mathrm{ml}$ )

\begin{tabular}{lccc}
\hline & \multicolumn{2}{c}{ Degradation rate $(/ \mathrm{h})$} & $\begin{array}{c}\text { Statistical } \\
\text { significance } \\
\text { of difference }\end{array}$ \\
\cline { 2 - 4 } Protein & $\begin{array}{c}\text { Untreated } \\
\text { protein }\end{array}$ & $\begin{array}{c}\text { Azo-treated } \\
\text { protein }\end{array}$ & $\begin{array}{c}P<0.001) \\
\text { NS }\end{array}$ \\
\hline Casein & 0.298 & 0.136 & 0.112 \\
Albumin & 0.113 & 0 & \\
\hline
\end{tabular}

NS, not significant $(P>0-10)$.

Use of $\mathrm{N}$ solubility to estimate rumen degradability is confounded by the magnitude of the NPN and IDN fractions. The NPN fraction, which can be considered 'predegraded', comprised 79, 65 and $80 \%$ of the buffer-soluble $\mathrm{N}$ in expeller-SBM, meat meal and lucerne, but only $19 \%$ for solvent-SBM (Table 7). Estimated IDN was 13 and $10 \%$ of the bufferinsoluble $\mathrm{N}$ for meat meal and lucerne, but less than $1 \%$ for expeller- and solventSBM.

It is difficult to assess the validity of the degradation rates determined in any rumen in vitro system. The rate determined for casein $(0 \cdot 395 / \mathrm{h}$, Table 7$)$ compared favourably with values observed for azo-casein $(0.346-0.463 / \mathrm{h}$, Table 6$)$, but was substantially lower than those found for $\left[{ }^{14} \mathrm{C}\right]$ casein $(0.631-0.746 / \mathrm{h}$, Table 6$)$. Estimated escapes (\%), computed assuming rumen passage of $0.06 \mathrm{~h}$, of 13 for casein, 28 for solvent-SBM, and 40 for lucerne hay may be compared with reported escapes of 10 (McDonald and Hall, 1957), 28 and 28 ((US) National Research Council, 1985) respectively. The Agricultural Research Council (1984) estimated escapes (\%) of 37 for SBM and 30 for dried lucerne at a rumen passage of $0.05 / \mathrm{h}$.

It should be noted that the values of protein escape given here include the IDN fraction, hence useful protein available for intestinal digestion may be overestimated. No consideration in this method has been given to essential amino acid pattern.

\section{Comments on method}

The extent of protein degradation is computed from net production of $\mathrm{NH}_{3}$ and TAA (i.e. the difference in $\mathrm{NH}_{3}$ and TAA concentrations between protein-containing and blank vessels). With slowly degraded proteins, these differences are small. For example, expellerSBM, degraded at an average rate of $0.045 / \mathrm{h}$ (Table 7), had mean net differences of 0.95 mM- $\mathrm{NH}_{3}$ and $0.44 \mathrm{~mm}$-TAA at $4 \mathrm{~h}$; mean blank $\mathrm{NH}_{3}$ and TAA concentrations (mM) from these four incubations at $4 \mathrm{~h}$ were 8.40 and 1.95 respectively. Differences become progressively larger with increased degradation rate. Net release for casein in the same studies was $2.98 \mathrm{~mm}-\mathrm{NH}_{3}$ and $2.42 \mathrm{~mm}$-TAA. Small net differences explain the poorer correlation coefficients for regressions with more slowly degraded proteins (Tables 4 and 7).

Addition of HS and CAP prevents microbial growth without significant reduction in degradation rate over $4 \mathrm{~h}$ (Table 6). However, these growth inhibitors would be expected eventually to interfere with normal microbial protein degradation. Others have been unsuccessful in applying the HS procedure (without CAP) to estimate degradation rate 
using $24 \mathrm{~h}$ incubations (Siddons et al. 1982). Therefore, it is recommended not to extend incubations beyond $4 \mathrm{~h}$.

A biexponential model was used earlier to describe degradation of cotton-seed meal (Broderick \& Craig, 1980). However, in the present studies it was assumed that degradation of feed proteins could be described as a single exponential. For all proteins tested, except BSA and meat meal, there was no significant $(P>0.20)$ improvement of fit using non-linear $v$. linear regression, indicating that this assumption was adequate. Degradation of BSA accelerated with time $(P<0.001)$, possibly due to early proteolytic steps altering tertiary structure to expose more of the polypeptide chain to hydrolysis (Wallace, 1983; Cotta \& Hespell, 1986). Degradation of meat meal slowed significantly $(P<0.001)$ with time.

Three different procedures were tested to stop microbial activity in samples from the in vitro incubations: killing by addition of aqueous solutions of TCA or cetyl trimethylammonium bromide (CTAB) (Broderick, 1984), or by adding a methylene chloride solution of CTAB plus TCA (MCT). When MCT reagent is mixed with the sample, CTAB and TCA are transferred from the organic phase to the aqueous phase, without loss of $\mathrm{NH}_{3}$ or amino acids, and with no change in sample volume as occurs when adding aqueous solutions. Hence, problems of pipetting-inaccuracy were reduced. Both TCA alone or the MCT method yielded equal degradation rates for expeller-SBM; samples appeared to be stable for at least $24 \mathrm{~h}$ at $4^{\circ}$ when killed by either technique. With CTAB, rates were comparable if samples were analysed immediately, but net $\mathrm{NH}_{3}$ and TAA concentrations tended to increase when samples were analysed the next day. The only protein giving different degradation rates with the three kill procedures was casein; apparent degradation rates were higher when using the CTAB or MCT methods. This may be due to release of intracellular amino acids (Annison, 1956; Broderick, 1978) which accumulate with this rapidly degraded protein.

An in vitro degradation study with twelve proteins and replicate samples at nine times will generate, including standards and recovery samples, over $350 \mathrm{NH}_{3}$ and TAA analyses, plus the mathematical and statistical computations to convert concentration values to degradation rates. Hence, the methodology described here may be largely limited to laboratories with automated equipment. However, assuming protein degradation can be described as a single exponential, a simplification of this procedure may be applied. For example, net release of $\mathrm{NH}_{3}$ and TAA between zero-time and $2 \mathrm{~h}$ could be used to estimate fractional degradation rates with substantially fewer analyses.

The author wishes to thank Mr M. J. Jackson for conducting in vitro incubations, $\mathrm{Mr}$ M. W. Meyer, Miss H. C. Mier and Miss K. Disch for sample analyses, Mr D. B. Ricker for computer programming for data collection and computations, and Dr R. J. Wallace of the Rowett Research Institute for the kind gift of casein, ovalbumin and BSA labelled with ${ }^{14} \mathrm{C}$.

\section{REFERENCES}

Agricultural Research Council (1984). The Nutrient Requirements of Ruminant Livestock, Suppl. 1. Slough: Commonwealth Agriculture Bureaux.

Annison, E. F. (1956). Biochemical Journal 64, 705-714.

Association of Official Analytical Chemists (1980). Official Methods of Analysis, 13th ed. Washington, DC: Association of Official Analytical Chemists.

Appel, W. (1974). In Methods of Enzymatic Analysis, 2nd ed., pp. 949-978 [H. U. Bergmeyer, editor]. New York: Academic Press.

Broderick, G. A. (1978). Journal of Nutrition 108, 181-190.

Broderick, G. A. (1982). In Protein Requirements for Cattle: Symposium, pp. 72-80 [F. N. Owens, editor]. Stillwater, Oklahoma: Oklahoma State University.

Broderick, G. A. (1984), Canadian Journal of Animal Science 64, suppl., 31-32.

Broderick, G. A. (1986). Journal of Dairy Science 69, 2948-2958. 
Broderick, G. A. \& Baithrop, J. E. Jr (1979). Journal of Animal Science 49, 1101-1111.

Broderick, G. A. \& Craig, W. M. (1980). Journal of Nutrition 110, 2381-2389.

Broderick, G. A. \& Kang, J. H. (1980). Journal of Dairy Science 63, 64-75.

Cotta, M. A. \& Hespell, R. B. (1986). In Control of Digestion and Metabolism in Ruminants, pp. 122-136 [L. P. Milligan, W. P. Grovum and A. Dobson, editors]. Englewood Cliffs, New Jersey: Prentice-Hall.

Craig, W. M. \& Broderick, G. A. (1981). Journal of Dairy Science 64, 769-774.

Craig, W. M., Hong, B. J., Broderick, G. A. \& Bula, R. J. (1984). Journal of Dairy Science 67, 2902-2909.

Eliman, M. E. \& Ørskov, E. R. (1984). Animal Production 38, 45-51.

Gale, E. F. \& Folkes, J. P. (1953). Biochemical Journal 53, 493-498.

Hartnell, G. F. \& Satter, L. D. (1979). Journal of Animal Science 48, 381-392.

Hungate, R. E. (1969). In Methods in Microbiology, vol. 3B, pp. 117-132 [J.R. Norris and D. W. Ribbons, editors]. New York: Academic Press.

Krishnamoorthy, U., Sniffen, C. J., Stern, M. D. \& Van Soest, P. J. (1983). British Journal of Nutrition 50, $555-568$.

McDonald, I. (1981). Journal of Agricultural Science, Cambridge 96, 251-252.

McDonald, I. W. \& Hall, R. J. (1957). Biochemical Journal 67, 400-405.

McDougall, E. I. (1948). Biochemical Journal 43, 99-109.

Mahadevan, S., Erfle, J. D. \& Sauer, F. D. (1979). Journal of Animal Science 48, 947-953.

Mahadevan, S., Erfle, J. D. \& Sauer, F. D. (1980). Journal of Animal Science 50, 723-728.

Mahler, H. R. \& Cordes, E. H. (1966). Biological Chemistry, pp. 810-811. New York: Harper \& Row.

Mangan, J. L. (1972). British Journal of Nutrition 27, 261-283.

National Research Council (1985). Ruminant Nitrogen Usage. Washington, DC: National Academy Press.

Ørskov, E. R. \& McDonald, I. (1979). Journal of Agricultural Science, Cambridge 92, 499-503.

Poos-Floyd, M., Klopfenstein, T. \& Britton, R. A. (1985). Journal of Dairy Science 68, 829-839.

Raab, L., Cafantaris, B., Jilg, T. \& Menke, K. H. (1983). British Journal of Nutrition 50, 569-582.

Siddons, R. C., Beever, D. E. \& Kaiser, A. G. (1982). Journal of the Science of Food and Agriculture 33, 609-613.

Steel, R. G. D. \& Torrie, J. H. (1960). Principles and Procedures of Statistics. New York: McGraw-Hill Book Company.

Wallace, R. J. (1983). British Journal of Nutrition 50, 345-355. 